\title{
BAJESOV KRITERIJUM ODLUČIVANJA U IZBORU POUZDANIH ISPORUČILACA
}

\author{
Dr Snežana Mijailović \\ Visoka poslovna škola strukovnih studija „Prof. dr Radomir Bojković“ Kruševac \\ e-mail: snezana.km@ptt.rs
}

\section{Sažetak}

Konkurentski uslovi na tržištu uslovljavaju organizacije da nađu način da smanje troškove neusaglašenosti, povećaju produktivnost $i$ poboljšaju uslugu kupaca. Orjentacija na kupce $i$ njegove potrebe zahteva kontinuirano poboljšavanje kvaliteta proizvoda $i$ usluga, niže cene, skraćivanje rokova isporuke i optimalne zalihe materijala na skladištu. Odluka preduzeća da li određene komponente kupiti ili proizvoditi predstavlja značajnu dilemu u uslovima neizvesnosti na tržištu. U radu je objašnjena tehnika za izbor pouzdanih isporučilaca odlivaka za proizvodnju grejnih ploča alternative korišćenjem apriori verovatnoća, koje se revidiraju sa procesom uzorkovanja. Opisana je tehnika prikupljanja podataka, tzv. binomnog uzorkovanja sa svim odgovarajućim elementima analize odlučivanja. Razvijen je model na osnovu kombinacije apriori raspodele sa procesom uzorkovanja, korišćenjem Bajesove teoreme za usklađivanje $i$ reviziju subjektivnih verovanja $i$ informacija iz apriori verovatnoća sa empirijskim podacima. Tako dobijene revidirane ili aposteriorne verovatnoće se potom koriste za nalaženje očekivanih troškova neusaglašenosti za svaku alternativu i za izbor optimalne stategije.
Abstract
Competitive terms and conditions on the market force organizations to find a way to reduce price of nonconformance increase

productivity and improve service to customers. Orientation to customer needs requires continuous improvement of quality of products and services, lower costs, shorter delivery time and the optimal inventory of materials in stock. Company's decision whether certain components should be bought or produced represents a significant dilemma in terms of uncertainty of the market itself. The paper explains the technique to choose a reliable supplier of castings for the production of heating plate an alternative to using a priori probability, which are reviewed by the sampling process. The paper presents us with the technique of data collection - binomial sampling, with all the appropriate elements of decision-making analysis. The model based on a combination of a priori distribution of the sampling process, using Bayes's theorem for compliance and audit subjective beliefs and information from the a priori probability of the empirical data. The resulting revised or posterior probabilities are then used to find the expected costs of non-compliance for each alternative and the choice of optimal strategy dedicated.

Ključne reči: Troškovi neusaglašenosti, Bajesova metoda, apriori verovatnoće, uslovne verovatnoće, aposteriorna verovatnoća, izbor pouzdanih isporučilaca.

Key words: price of nonconformance, Bayes methods, a priori probability, conditional probability, a posteriori probability, selection of reliable suppliers 


\section{Uvod}

Danas postoji tendencija da se organizacije odlučuju da kupuju komponente od isporučilaca koji su proizvođači velikih serija. Razlog za ovakvu odluku leži u rentabilnom poslovanju. U uslovima surove konkurencije i neizvesnosti na tržištu, sve je prisutniji sistematičan prilaz nabavci usaglašenih proizvoda (prema specifikaciji) po nižim nabavnim cenama. Organizacija analizom vrednosti nabavke proizvoda dovodi u vezi faktore: trošak, kvalitet $i$ rok isporuka. Funkcija nabavke u organizaciji ima zadatak da uspostavi optimalani odnos između troškova nabavke, kvaliteta i rokova isporuka, kako bi se odredili optimalni uslovi pri izboru isporučilaca za isporuku usaglašenih proizvoda. Analiza troškova nabavke se proučava sa aspekta kvaliteta kao odlučujućeg faktora $\mathrm{u}$ odnosu na konkurentske organizacije, dok je aspekt roka isporuka zavisan od neposrednih potreba $u$ procesu proizvodnje. Odluka menadžera o izboru isporučioca zasniva se na Bajesovom kriterijumu prema kojem je optimalna odluka ona koja maksimizira očekivanu korisnost, odnosno očekivanu novčanu isplativost. U radu je prikazan ilustrativni primer primene Bajesove metode $\mathrm{u}$ izboru pouzdanih isporučilaca i izvršena analiza rezultata.

\section{Kvalitet u procesu nabavke}

Šta je kvalitet u poslovanju? Odgovor je u novoj japanskoj proizvodnoj filozofiji koja je definisana početkom 70-tih godina prošlog veka. Japansko shvatanje pojma kvaliteta svakako je danas svetski standard. Međutim, njegovo razumevanje i prihvatanje nije jednostavno i zahteva razumevanje osnovnih principa japanske proizvodne filozofije. Kompleksnost pojma kvaliteta proizilazi iz intenzivnog trenda promene odnosa kupaca prema kvalitetu. U rezultatima istraživanja iz 1979. godine, oko $75 \%$ kupaca smatra da je najvažnije da kvalitet proizvoda bude visok, dok u 1986. godini taj broj je 80-90 \% kupaca [3]. Suština ovog pristupa je u tome da se kao zainteresovane strane za proizvodnju, pored samog preduzeća u okviru kojeg se ona odvija, pojavljuju i korisnici, odnosno kupci proizvoda, kao i isporučioci potrebne opreme i materijala za proizvodnju. Izbor isporučilaca treba da obezbedi da se na najbolji način zadovolje tehničke, komercijalne, finansijske i druge potrebe organizacije. Cilj upravljanja snabdevanjem jeste isporuka pravog proizvoda, na pravo mesto, u pravo vreme, pod pravim uslovima i sa pravom cenom [1]. Nabavka je značajna prometna funkcija, ali često se degradirala kao prodaja sa obrnutim predznakom. Pedesetih godina prošlog veka, u teoriji i praksi, promenilo se shvatanje da nabavna služba nije samo „druga strana medalje" prodaje, već da obavlja i aktivnu funkciju. Rezultat procene po mišljenju analitičara je da $1 \%$ ušteda $\mathrm{u}$ nabavci, kao rezultat efikasnog procesa kupovine, utiče sa $15 \%$ na nominalni rast profita organizacije [4].

Savremeni uslovi poslovanja uslovljavaju povećanje broja kriterijuma za ocenjivanje faktora za izbor pouzdanih isporučilaca. Tendencija smanjenja stope privrednog rasta je znatno uticala na manji broj isporučilaca, što dodatno komplikuje određivanje statusa novim i postojećim isporučiocima. Organizacija sa isporučiocima koji imaju status „pouzdan”, nastoji da uspostavi partnerski odnos sa dugoročnom saradnjom $\mathrm{u}$ isporučivanju proizvoda $\mathrm{u}$ ugovorenim rokovima i kvalitetom. Ovakvim odnosom sa isporučiocima postiže se sklapanje dugoročnih ugovora i uspostavljaju potpuno novi odnosa poverenja, otvorenosti i kooperacije. Ocenjivanje novih i postojećih isporučilaca je kontinuirani proces i sprovodi se periodično $\mathrm{u}$ toku godine. Određivanje statusa isporučilaca sprovodi se na kraju ili u toku godine, ukoliko ocene postojećih isporučilaca padnu ispod donje propisane granice (više isporuka proizvoda neusaglašenog kvaliteta).

\subsection{Izbor pouzdanih isporučilaca}

Izbor isporučilaca je proces koji počinje javnim oglašavanjem nabavke, direktnim kontaktom sa isporučiocem ili upućivanjem upitnika na popunjavanje isporučiocu [7]. Povratne informacije koje se dobijaju od isporučilaca, kao odgovor na ponudu 
naručioca, predstavljaju ulazne podatke za bazu podataka o isporučiocima. Parametri za vrednovanje performansi isporučilaca u bazi podataka su vrednosno ocenjeni i na osnovu njih se proces nabavke prati, meri i kontinualno poboljšava. Baza podataka o isporučiocima obuhva sledeće parametre:

- moć isporučilaca - ukupna vrednost redovne nabavke po isporučiocima

- kvalitet isporučilaca - procentualno učešće troškova reklamacije po isporučiocu u ukupnoj nabavnoj vrednosti tog isporučioca

- ažurnost rešavanja reklamacija procentualno učešće rešenih reklamacija prema broju ukupnih reklamacija isporučioca

- rokovi isporuka - poštovanje ugovorenih rokova isporuka od strane isporučilaca

- tačnost isporuka - prosečni troškovi kašnjenja ugovorenih isporuka prema broju dana na ugovoreni rok

- cena isporučenog proizvoda nabavna cena isporučenih proizvoda

- troškovi nabavke isporučenih proizvoda - procentualno učešće troškova neusaglašenosti proizvoda $\mathrm{u}$ nabavnoj ceni po isporučiocima

- vanredni troškovi kvaliteta procentualno učešće troškova neusaglašenosti proizvoda, po osnovu skrivene mane $u$ procesu proizvodnje $\mathrm{u}$ vrednosti proizvodnje

- ispunjavanje ugovorenih narudžbi procentualno učešće vrednosti neisporučenih proizvoda u ukupnoj vrednosti narudžbi po isporučiocima

- servisiranje - troškovi servisiranja u garantnom roku i vreme servisiranja od strane isporučilaca od prijavljene reklamacije

- isporučioci koji poseduju sertifikat: ISO 9001:2000, ISO 14000:2000, ISO 9004:2000

Odluka o izboru isporučioca je dokumentovan postupak, koji pruža mogućnost isporučiocima da sagledaju svoju poziciju na osnovu uvida $u$ značajnost pojedinih kriterijuma za poboljšanje budućeg statusa. Izbor pouzdanih isporučilaca predstavlja kontinuirani proces koji je moguće automatizovati projektovanjem modela.

U narednom poglavlju je prikazana primena Bajesove teoreme u modelu odlučivanja za izračunavanje aposteriornih verovatnoća i njihova primena $\mathrm{u}$ donošenju odluka o izboru pouzdanih isporučilaca.

\section{Primena Bajesove teoreme u odlučivanju}

Odlučivanje u uslovima neizvesnosti ne podrazumeva jedan - najbolji kriterijum za izbor strategije. Postoje različiti kriterijumi na osnovu kojih se nameću racionalni razlozi koji opravdavaju i preporučuju njihovu upotrebu. Donosilac odluke po svom ličnom stavu trebalo bi da se opredeli za neki od tih kriterijuma. Cilj u izboru kriterijuma optimalnosti je mogućnost da se smanji rizik u donošenju odluka. U tom slučaju je jasno zašto se ne može govoriti o najboljem kriterijumu za izbor strategije. Primena Bajesove teoreme nastoji da se na osnovu poznate apriori verovatnoće, koja predstavlja rezultat subjektivne procene menadžera zasnovane na praćenju događaja u prošlosti, omogući realizacija određenog događaja. Informacije slučajne promenljive $X$ dobijene kroz uzorkovanje, pri čemu se računa vrednost tzv. statistike iz uzorka ima raspodelu i naziva se raspodelom uzorkovanja, koju označavamo $P\left(X=x \mid w_{j}\right)$ ili $P\left(x \mid w_{j}\right)$. Kombinovanje informacija uzokrovanjem sa apriori informacijama, menadžeru omogućava verodostojnost odigravanja svakog mogućeg realnog stanja posle (aposteriorno) procesa uzorkovanja. Kombinovanje apriori verovatnoća i informacija uzorkovanja u novu aposteriori raspodelu, koja se naziva i revidirana raspodela jeste karakteristika primene Bayes-ove teoreme [5]:

$$
P\left(w_{j} \mid x\right)=\frac{P\left(x \mid w_{j}\right) \cdot P\left(w_{j}\right)}{\sum_{k=1}^{N} P\left(x w_{k}\right) \cdot P\left(w_{k}\right)}
$$

gde je: $w_{j} \quad j$-ta klasa i $x$ predstavlja osobine/karakteristike vektora. Osnovno pravilo odlučivanja (određene klase) je izbor 
klase $w_{j}$ za najbolju uslovnu verovatnoću $P\left[w_{j} \mid x\right]$. Izraz (2.1) je raščlanjen na:

- $P\left[w_{j}\right]$ - apriorna verovatnoća od $w_{j}$

- $P\left[x \mid w_{j}\right]$ - uslovna verovatnoća od $x$ za dato $w_{j}$

- $P\left[w_{j} \mid x\right]$-aposteriorna verovatnoća od $w_{j}$ za dato $x, \quad j=1,2, \ldots n$.

Pravila odlučivanja se daju u tabelarnoj formi tipa: za $X-P(x) \rightarrow a$, gde je $x$ rezultat uzorkovanja, $p$-pravilo odlučivanja i $a$ - najbolja akcija.

U slučaju da menadžer nastoji da smanji neizvesnost, on koristi različite procedure pri izboru najbolje akcije za rešavanje problema odlučivanja. Dodeljuje se za svaku akciju, zavisno od raspodele apriori verovatnoće za pojedinačna stanja. Izračunava se očekivana vrednost za svaku akciju i bira akciju čija je očekivana vrednost najpovoljnija za njega. Očekivana novčana vrednost $(O N V)$ definiše se kao promenljiva stanja i ako uzima vrednosti $S_{1}, S_{2}, \ldots, S_{m}$, sa raspodelom apriori verovatnoća $P\left(S_{1}\right), P\left(S_{2}\right), \ldots, P\left(S_{m}\right)$, tada se očekivana novčana vrednost akcija $a_{i}$ obeležena sa $O N V\left(a_{i}\right)$ može definisati izrazom [2]:

$$
\text { ONV } \quad\left(a_{i}\right)=\sum_{j=1}^{m} p_{i j} P\left(S_{j}\right)
$$

gde je $p_{i j}$ plaćanje ako menadžer izabere akciju $a_{i}$ i realizuje se stanje $s_{j}$. Menadžer donosi odluku za akciju kod koje je očekivana novčana vrednost optimalna. Kriterijum se naziva $O N V$ maksimuma, tj. izabrana akcija $a_{k}$ ako je:

$$
O N V\left(a_{i}\right)=\max \left\{O N V\left(a_{i}\right)\right\}
$$

U slučaju troškova izabrane akcije za koju je očekivana novčana vrednost minimalna, izraz glasi:

$$
O N V\left(a_{i}\right)=\min \left\{\underset{a_{i}}{\{O N V}\left(a_{i}\right)\right\}
$$

gde je $O N V\left(a_{i}\right)$ očekivana novčana vrednost akcije $a_{i}$. Primena $O N V$ kriterijuma sa više akcija zahteva nekoliko koraka:
Korak1: Identifikovati sve raspoložive alternative odlučivanja $a_{i}(\mathrm{i}=1,2, \ldots, \mathrm{n})$ i kriterijume $s_{j}(j=1.2, \ldots, n)$.

Korak 2: Odrediti verovatnoću $p_{i j}$ za svaku akciju $a_{i}$ i stanje $s_{j}$.

Korak 3 Dodeliti apriori verovatnoće $P\left(s_{j}\right)$ svakom stanju $\mathrm{s}_{\mathrm{j}}$.

Korak 4 : Izračunati $O N V$ za svaku akciju $a_{i}$.

Korak 5: U slučaju da je kriterijum profit, tada treba izabrati akciju čija $O N V$ ima maksimalnu vrednost od svih $O N V$ dobijenih u koraku 4 i za kriterijum troškova izabrati akciju čija $O N V$ ima minimalnu vrednost od svih $O N V$ dobijenih u koraku 4.

Bajesova teorija ima elemente statičkog ali isto tako i dinamičkog odlučivanja, u kojem ishod jedne prethodne odluke ima uticaj na sledeće odluke [6]. Primena Bajesovog kriterijuma $\mathrm{u}$ rešavanju problema realnog sistema, omogućava menadžeru da planira strategiju međusobno povezanih akcija i na osnovu njih - prognozira događaje $u$ budućnosti.

\section{Ilustrativni primer}

Razvoj modela za rešavanje problema izbora pouzdanih isporučilaca odlivaka za proizvodnju GP u uslovima neizvesnosti spovodi se na osnovu analiza odlučivanja sa uzorkovanjem. Ulazna kontrola kvaliteta obavlja kontrolu isporučenih odlivaka na osnovu metode $A Q L$ u Fabrici elektrotermičkih proizvoda u Kraljevu. Ulazni podaci su vrednost vanrednih troškova dorade neobrađenih isporučenih odlivaka od tri isporučilaca na liniji strugova (prilog 1).

Podaci su prikupljeni na osnovu Zapisnika o škartu Operativne kontrole kvaliteta (OKK). Fabrika elektrotermičkih proizvoda (FETP) je nabavljala neobrađene odlivke od livniceKikinda $(L K)$, livnice-Mačkatica $(L M)$ i železara-Ilijaš“ ( $\check{Z} I)$ u serijama od 30.000 komada odlivaka na 10 dana. Analizom izveštaja o kvalitativnom prijemu isporučenih serija neobrađenih odlivaka Ulazne kontrole kvaliteta prikupljeni su podaci za preispitivanje statusa $\mathrm{i}$ izbor 
isporučioca. Isporučeni neobrađeni odlivci obrađuju se na liniji strugova i uzorkovanje se kontinuirano vrši od strane radnika na strugu. Troškovi neusaglašenosti isporučenih neobrađenih odlivaka je obračunato na osnovu prosečene nabavne cene (tabela 2.2). Menadžer u donošenju odluka rukovodi se kriterijumima $Y_{1}-$ vrednost vanrednih troškova dorade neobrađenih odlivaka i $Y_{2}$ vrednost vanrednih troškova prslih neobrađenih odlivaka na liniji strugova $u$ svakoj isporučenoj seriji. Apriorne verovatnoće su subjektivne ocene menadžera zasnovane na Izveštajima o škartu/doradi $O K K$ o isporučenim neobrađenim odlivcima iz prijemnog magacina, na osnovu trebovanja u Pogon strugova:

- u $P\left(X_{1}\right)=50 \%$ vrednosti nabavke isporučenih neobrađenih komada odlivaka $L K$ su $P\left(Y_{1}\right)=7 \%$ vanredni troškovi dorade neobrađenih odlivaka $\mathrm{i}$ $P\left(Y_{2}\right)=3 \%$ vanredni troškovi prslih neobrađenih odlivaka na liniji strugova,

- u $P\left(X_{2}\right)=30 \%$ vrednosti nabavke isporučenih neobrađenih komada odlivaka $L M$ su $P\left(Y_{1}\right)=11 \%$ vanredni troškovi dorade odlivaka i $P\left(Y_{2}\right)=4 \%$ vanredni troškovi prslih neobrađenih odlivaka na liniji strugova $\mathrm{i}$

- u $P\left(X_{3}\right)=20 \%$ vrednosti nabavke isporučenih neobrađenih komada odlivaka ŽI su $P\left(Y_{1}\right)=17 \%$ vanredni troškovi dorade odlivaka i $P\left(Y_{2}\right)=5 \%$ vanredni troškovi prslih neobrađenih odlivaka.

Menadžer je definisao akciju :

$\boldsymbol{a}_{\boldsymbol{1}}$ - naručiti odlivke od isporučioca sa minimalnim vanrednim troškovima dorade neobrađenih odlivaka i

$\boldsymbol{a}_{2}$ - naručiti odlivke od isporučioca sa minimalnim vanrednim troškovima prslih neobrađenih odlivaka na liniji strugova.

Određivanjem apriornih verovatnoća za date alternative i verovatnoće za izabrane kriterijume moguće je izračunati aposteriornu verovatnoću primenom Bajesove metode. Ovom metodom procenjuju se očekivani vanredni troškovi neusaglašenosti neobrađenih odlivaka. Proces strugarske obrade odlivaka sa uzorkovanjem je kontinuirani proces gde promenljiva $X$ uzima diskretne vrednosti u intervalu $[0,1]$. Procenom očekivanih troškova neusaglašenosti metodom $O N V$ kriterijuma sprovodi se izbor pouzdanog isporučioca. Analiza rešenja primenom metode $O N V$ realizuje se kroz pet koraka.

Korak 1 - postavka problema je izbor pouzdanog isporučioca odlivaka, kod kojeg su očekivani vanredni troškovi obrade isporučenih neobrađenih odlivaka minimalni.

Korak 2 - strukturiranje problema (identifikacija problema, izbor mogućih aliternativa, izbor kriterijuma za vrednovanje rešenja).

Korak 3 - uslovne verovatnoće su izračunate korišćenjem binomne raspodele za $X$ broj komada isporučenih odlivaka u slučajnom uzorku, na osnovu vanrednih troškova obrade i predstavlja analizu sa binomnim uzorkovanjem.

Za određivanje kriterijuma optimalnosti u izboru isporučilaca koriste se aposteriorne verovatnoće izračunate Bajesovom formulom. Zbir uslovnih verovatnoća $\mathrm{za}$ izabrane kriterijume je 1 .

Korak 4 - vrednovanje i izbor rešenja na osnovu očekivanih vanrednih troškova dorade isporučenih neobrađenih odlivaka.

Korak 5 - analiza rezultata (primena rešenja i vrednovanje rezultata) i donošenje odluke o izboru pouzdanog isporučioca.

Postavka problema je u određivanju apriornih verovatnoća za isporučene neobrađene odlivke po tipu od isporučioca. U slučaju da se uzima procenat neusaglašenih komada isporučenih neobrađenih odlivaka po tipu, problem se dodatno komplikuje zbog različitih nabavnih cena za svaki tip odlivka. Međutim, isporučeni neobrađeni odlivci se obrađuju na liniji strugova, gde svaka operacija ima vrednosni obračun. $\mathrm{Na}$ osnovu prethodnog obrazloženja, problem se svodi na to da slučajna promenljiva $X_{i}$ predstavlja učešće vanrednih troškova dorade isporučenih neobrađenih odlivaka u ukupnoj vrednosti 
nabavke. Apriorne verovatnoće (tabela 2.2) za $X_{i}$ su diskretne vrednosti za kriterijume:

$Y_{1}$ - učešće vanrednih troškova dorade isporučenih neobrađenih odlivaka na liniji strugova

$\boldsymbol{Y}_{2}$ - učešće vanrednih troškova prslih isporučenih neobrađenih odlivaka na liniji strugova

Tabela 2.2 Apriorne verovatnoće za izabrane kriterijume po isporučiocu

\begin{tabular}{|lll|r|r|}
\hline \multicolumn{3}{|c|}{ Alternative } & \multicolumn{2}{c|}{ Kriterijumi } \\
\cline { 4 - 5 } \multicolumn{2}{|c|}{} & \multicolumn{1}{|c|}{$Y_{1}$} & \multicolumn{1}{c|}{$Y_{2}$} \\
\cline { 4 - 5 } \multicolumn{2}{|c|}{} & Dorada & \multicolumn{1}{c|}{ Prsli } \\
\hline$L K$ & $X_{1}$ & 0,50 & 0,07 & 0,03 \\
\hline$L M$ & $X_{2}$ & 0,30 & 0,11 & 0,04 \\
\hline$\check{Z} I$ & $X_{3}$ & 0,20 & 0,17 & 0,05 \\
\hline
\end{tabular}

$P[X=x \mid n, \pi]=[1 ! / x !(1-x) !] \pi^{x}(1-\pi)^{n-x}, \quad k=0,1, \ldots, n$ odnosno, za vrednost $X=0 \quad \mathrm{i}$ $\pi=0,07$ (vrednost za kriterijum $Y_{l}$ ) $\quad$ su izračunate na osnovu izraza:

$P[X=0 \mid n=1, \pi=0,07]=[11 / 0 !(1-0)] \cdot] 0,070(1-0,07)^{1-0}=0,93$

predstavljaju uslovne verovatnoće (prilog 2). Aposteriorne verovatnoće za oba kriterijuma i za dati rezultat uzorkovanja su izračunate Bajesovom teoremom (2.1), na osnovu apriori verovatnoća $P\left(w_{j}\right)$ iznosi $P\left(w_{1}\right)=0,5$, $P\left(w_{2}\right)=0,3, \quad P\left(w_{3}\right)=0,2$. Način izračunavanja aposteriori verovatanoća su za $P\left(w_{j}=0,07 \mid X=0\right)$ prikazane detaljno, a za $X$ $=1$ vrednosti su prikazane u tabeli (prilog 3 i 4). Izraz je:

$$
\begin{aligned}
& \left.P\left(w_{j}=0,0\right\rceil X=0\right)=\frac{P\left(X=0 w_{1}=0,07\right) \cdot P\left(w_{1}=0,07\right)}{P\left(X=0{ }_{w_{1}}=0,07\right) P\left(w_{1}=0,07\right)+P\left(X=0 \mid w_{1}=0,1\right) P\left(w_{1}=0,11\right)+P\left(X=0 w_{1}=0,17\right) P\left(w_{1}=0,17\right)}= \\
& \frac{0,93 \cdot 0,50}{0,93 \cdot 0,50+0,89 \cdot 0,30+0,83 \cdot 0,20}=0,518
\end{aligned}
$$

Pretpostavimo da je menadžer, pre nego što donese odluku o izboru pouzdanih isporučilaca za odlivke, prikupio i dodatne informacije. Najbolji način za prikupljanje dodatnih podataka je da se sprovede uzorkovanje od $n$ komada neobrađenih odlivaka iz isporučenih serija od isporučilaca na liniji strugova. U primeru se koristi slučajno izabran uzorak od $n=1$ odlivaka iz isporučene serije, zbog jednostavnosti u predstavljanju modela (tabela 2.3). Menadžer, na osnovu eksperimenta, očekuje da se dobiju informacije o očekivanim troškovima neusaglašenosti. Rezultati uzorkovanja zadovoljavaju pretpostavke binomne raspodele, zbog čega se koristi za nalaženje uslovne verovatnoće broja neusaglašenih komada odlivak u uzorku, za datu verovatnoću $\pi$, izraz je:

$P[x \mid n=1, s]=P[X=x \mid n=1, \pi]=\left[1 ! / x !(1-x) ! \cdot s^{x}(1-s)^{2-x}\right.$

$\mathrm{U}$ uzorku od $n=1$ odlivaka, slučajna promenljiva $X$ - broj komada neobrađenih odlivaka, može uzeti vrednost 0 -odlivak za doradu ili 1 - odlivak je prsao. Prikupljeni podaci uzorkovanjem odlivaka izračunava se binomna verovatnoća, gde je opšti izraz:
Menadžer u donošenju odluka u izboru pouzdanih isporučilaca rukovodi se funkcijom troškova za akciju $a_{1}$ za kriterijum $Y_{1}$ - dorada odlivaka i $a_{2}$ za kriterijum $Y_{2}-$ prsli odlivci. Prosečna cena dorade neobrađenog odlivka je $0,11 € /$ kom i za prsli odlivak $0,98 € /$ kom. Funkcija troškova neusaglašenosti za akciju $a_{1} i a_{2}$ su:

$$
\begin{aligned}
& P\left(a_{1}\right)=30.000 \cdot 0,11 s_{j}=3.300 \cdot s_{j} \\
& P\left(a_{2}\right)=30.000 \cdot 0,98 \cdot s_{j}=29.400 \cdot s \quad j=1,2,3
\end{aligned}
$$

Vrednosti u tabeli odlučivanja su dobijene iz funkcija troškova neusaglašenosti (2.5). Očekivani troškovi neusaglašenosti (žaljenje) za akcije $a_{1}$ i $a_{2}$ su ponderisane aposteriori verovatnoće, koje se u ovom primeru praktično vrlo malo razlikuju zbog male veličine uzorka $n=1$. Softversko rešenje proračuna Bajesovom metodom je programirano u programskom jeziku $C^{\# \#} \mathrm{u}$ Windows okruženju (prilog 5). 


\section{Analiza rezultata}

Analiza tabele odlučivanja za akcije $a_{1}$ i $a_{2}$ na osnovu očekivanih vanrednih troškova neusaglašenosti za kriterijum $Y_{1}$ i $Y_{2}$ za izabrane isporučioce sadrži:

- najniže očekivane vanredne troškove neusaglašenosti za kriterijum $Y_{1}$ - doradu, za vrednost uzorkovanja $X=0$, kod železare

„Ilijaš“ - $104 €$, kod livnice „Mačkatice“ $108 €$ i za livnicu „Kikinda“ - $120 €$ po svakoj isporuci odlivaka.

Isporuka odlivaka je najniža kod železare Ilijaš $(20 \%)$, odnosno očekivani vanredni troškovi dorade nisu u srazmeri, što ukazuje na loš kvalitet odlivaka. Najbolja odluka je izbor isporučioca odlivaka livnica - Kikinda - za kriterijum $Y_{2}$ - prsli odlivci, očekivani troškovi neusaglašenosti su najniži kod livnice „Kikinda“ - $302 €$, kod livnice „Mačkatice“-380 €, kod železare „Ilijaš“ $491 €$ po isporuci odlivaka.

Analiza rezultata je ukazala da je za FETP najbolja akcija $a_{l}$, odnosno da livnica „Kikinda“ predstavlja pouzdanog isporučioca odlivaka.

\section{Zaključak}

Bajesov kriterijum odlučivanja je ukazao na sledeće implikacije:

Aposteriorna analiza je opravdala primenu u reviziji Izveštaja o statusu isporučilaca, jer reflektuje stepen očekivanja, pre nego relativne frekvencije u uzorcima.

Bajesov pristup reviziji apriori verovatnoća je realni način razmišljanja menadžera, koji vrši proces integrisanja novih informacija $u$ procesu racionalizacije njihovih prethodnih odluka, kao kontrolu i realizaciju svojih budućih odluka.

\section{Bibliografija}

1. Copra S., Meindi P., Sypply Chain Management: Strategy, Planning, and Operation, Prentice-Hall, Inc., 2001.

2. Čupić M., Suknović M., Odlučivanje, šsto prerađeno i dopunjeno izdanje, FON, Beograd, 2008.

3. Davenport, T.H., Short, J.E., The New Industrial Engenering, Slon Management Review, Summer, 11-27, 2000.

4. Hammer, M. and Champy, J., Reengineering the Corporation, New York: HarperCollins Publishers, 1993.

5. Lubik T., Schorfheide F., A Bayesian Look at New Open Economy, MacrDeconimics,Johns Hopkins University of Pennsilvania, 2005.

6. Petrašinović P., Lalović G., Bajesov metod i njegova primena u poslovnom odlučivanju, časopis Marketing, br. 4, Beograd, 2003.

7. Zakon o javnim nabavkama, Službeni glasnik br. 50/09, Beograd, 2009.

\section{Istorija rada:}

Rad primljen: 07.05.2013.

Prva revizija: 23.05.2013.

Prihvaćen: 26.05.2013. 


\section{PRILOG 1}

Troškovi neusaglašenosti neobrađenih odlivaka livnice-Kikinda

\begin{tabular}{|c|c|c|c|c|c|}
\hline \multirow{3}{*}{$\begin{array}{l}\text { Tip } \\
\text { grejne } \\
\text { ploče }\end{array}$} & \multirow{3}{*}{$\begin{array}{l}\text { Isporučeni } \\
\text { odlivci }\end{array}$} & \multicolumn{4}{|c|}{$\begin{array}{c}\text { Troškovi neusaglašenosti } \\
\text { (neobrađeni odlivci isporučenih od } \\
\text { livnice - Kikinda) }\end{array}$} \\
\hline & & \multicolumn{2}{|c|}{ dorada } & \multicolumn{2}{|c|}{ prsli odlivci } \\
\hline & & kom & $€$ & kom & $€$ \\
\hline$\varnothing 80$ & 128.882 & 1.450 & 158,65 & 1.450 & 480,50 \\
\hline Ø 110 & 21.556 & 510 & 40,00 & 275 & 155,60 \\
\hline Ø 145 & 444.247 & 16.657 & $1.923,41$ & 3.872 & $3.417,83$ \\
\hline$\varnothing 180$ & 433.580 & 17.764 & $2.396,48$ & 6.980 & $8.831,65$ \\
\hline$\varnothing 220$ & 68.797 & 4.516 & 601,48 & 927 & $1.688,13$ \\
\hline$\sum$ & 1.097 .062 & 40.897 & $5.120,02$ & 13.504 & $14.573,71$ \\
\hline
\end{tabular}

Troškovi neusaglasenosti neobrađenih odlivaka livnice - Mačkatice

\begin{tabular}{|c|c|c|c|c|c|}
\hline \multirow{3}{*}{$\begin{array}{l}\text { Tip } \\
\text { grejne } \\
\text { ploče }\end{array}$} & \multirow{3}{*}{$\begin{array}{l}\text { Isporučeni } \\
\text { odlivci }\end{array}$} & \multicolumn{4}{|c|}{$\begin{array}{c}\text { Troškovi neusaglašenosti } \\
\text { (neobrađeni odlivci isporučeni od } \\
\text { livnice - Mačkatice) }\end{array}$} \\
\hline & & \multicolumn{2}{|c|}{ dorada } & \multicolumn{2}{|c|}{ prsli odlivci } \\
\hline & & kom & $€$ & kom & $€$ \\
\hline$\varnothing 80$ & 128.882 & 1.090 & 98,70 & 837 & 277,36 \\
\hline Ø 110 & 21.556 & 420 & 32,95 & 298 & 168,61 \\
\hline$\varnothing 145$ & 444.247 & 14.345 & 1664,79 & 3.015 & $2.661,35$ \\
\hline$\varnothing 180$ & 433.580 & 15.863 & $2.137,79$ & 6.467 & $8.182,56$ \\
\hline Ø 220 & 68.797 & 3.638 & 489,79 & 812 & $1.478,71$ \\
\hline$\sum$ & 1.097 .062 & 35.356 & $4.424,02$ & 46.785 & $12.768,59$ \\
\hline
\end{tabular}

Troškovi neusaglašenosti neobrađenih odlivaka železare Ilijaš

\begin{tabular}{|c|c|c|c|c|c|}
\hline \multirow{3}{*}{$\begin{array}{l}\text { Tip } \\
\text { grejne } \\
\text { ploče }\end{array}$} & \multirow{3}{*}{$\begin{array}{l}\text { Isporučeni } \\
\text { odlivci }\end{array}$} & \multicolumn{4}{|c|}{$\begin{array}{c}\text { Troškovi neusaglašenosti } \\
\text { (neobrađeni odlivci isporučeni od } \\
\text { železare- Ilijaš) }\end{array}$} \\
\hline & & \multicolumn{2}{|c|}{ dorada } & \multicolumn{2}{|c|}{ prsli odlivci } \\
\hline & & kom & $€$ & kom & $€$ \\
\hline$\varnothing 80$ & 128.882 & 1.440 & 130,40 & 763 & 251,79 \\
\hline$\varnothing 110$ & .556 & 360 & 28,57 & 207 & 117,12 \\
\hline Ø 145 & 444.247 & 14.738 & $1.647,78$ & 3.528 & $3.114,18$ \\
\hline$\varnothing 180$ & 433.580 & 16.813 & $2.286,64$ & 5.655 & $7.153,57$ \\
\hline$\varnothing 220$ & 68.797 & 4.224 & 569,49 & 801 & $1.458,67$ \\
\hline$\sum$ & 1.097 .062 & 84.360 & $4.662,88$ & 95.314 & $12.095,33$ \\
\hline
\end{tabular}




\section{PRILOG 2}

Aposteriorna analiza za izabrane kriterijume

\begin{tabular}{|c|c|c|c|c|c|c|c|c|c|c|}
\hline \multirow{3}{*}{$\begin{array}{l}\text { Apri. } \\
\text { vera. }\end{array}$} & \multicolumn{2}{|c|}{ Kriterijum } & \multicolumn{4}{|c|}{ Uslovne verovatnoće } & \multicolumn{4}{|c|}{ Složene verovatnoće } \\
\hline & \multirow{3}{*}{$\begin{array}{l}Y_{l} \\
007\end{array}$} & \multirow{3}{*}{$Y_{2}$} & \multirow{3}{*}{$\begin{array}{l}P\left(X=q \mid y_{1}\right) \\
0.93\end{array}$} & \multirow{3}{*}{$\begin{array}{l}\left.F X=d y_{2}\right) \\
0.97\end{array}$} & \multirow{3}{*}{$\begin{array}{l}P(X=1 \mid y \\
0.07\end{array}$} & \multirow{3}{*}{$\begin{array}{l}P\left(X=1 \mid y_{2}\right) \\
0.03\end{array}$} & \multirow{2}{*}{\multicolumn{2}{|c|}{$\begin{array}{c}X_{j}=0 \\
P\left(Y_{I}\right) \cdot P\left(X_{i} \mid Y_{l}\right)\end{array}$}} & \multirow{2}{*}{\multicolumn{2}{|c|}{$\begin{array}{c}X_{j}=1 \\
P\left(Y_{2}\right) P\left(X_{i} \mid Y_{2}\right)\end{array}$}} \\
\hline & & & & & & & & & & \\
\hline 0.50 & & & & & & & 0.465 & 0.485 & 0.035 & 0.015 \\
\hline 0,30 & 0,11 & 0,04 & 0,89 & 0,96 & 0,11 & 0,04 & 0,267 & 0,288 & 0,033 & 0,012 \\
\hline 0,20 & 0,17 & 0,05 & 0,83 & 0,95 & 0,17 & 0,05 & 0,166 & 0,190 & 0,034 & 0,010 \\
\hline & & & & & $\sum$ & & 0,898 & 0,963 & 0,102 & 0,037 \\
\hline
\end{tabular}

* nastavak prethodne tabele

\begin{tabular}{|l|l|l|l|}
\hline \multicolumn{3}{|c|}{ Aposteriorna verovatnoća } \\
\hline \multicolumn{2}{|c|}{$P\left(Y_{1}\right)$} & \multicolumn{1}{c|}{$P\left(Y_{2}\right)$} \\
\hline 0,518 & 0,504 & 0,343 & 0,343 \\
\hline 0,297 & 0,299 & 0,323 & 0,323 \\
\hline 0,185 & 0,197 & 0,334 & 0,334 \\
\hline 1,000 & 1,000 & 1,000 & 1,000 \\
\hline
\end{tabular}

\section{PRILOG 3}

Tabela odlučivanja za $X=0$

\begin{tabular}{|c|c|c|c|c|c|c|c|c|}
\hline \multirow{2}{*}{$\begin{array}{l}\text { Apri. } \\
\text { vero. }\end{array}$} & \multicolumn{2}{|c|}{ Kriterijum } & \multicolumn{2}{|c|}{$\begin{array}{c}\text { Uslovna } \\
\text { verovatnoća }\end{array}$} & \multirow{2}{*}{\multicolumn{2}{|c|}{$\begin{array}{c}\begin{array}{c}\text { Složena } \\
\text { verovatnoća }\end{array} \\
X_{j}=0 \\
P\left(Y_{1}\right) \cdot P\left(X_{i} \mid Y_{1}\right)\end{array}$}} & \multirow{2}{*}{\multicolumn{2}{|c|}{$\begin{array}{c}\text { Aposteriorna } \\
\text { verovatnoća } \\
\qquad P\left(Y_{l}\right)\end{array}$}} \\
\hline & \multirow{2}{*}{$\begin{array}{r}Y_{1} \\
0,07\end{array}$} & \multirow{2}{*}{$\begin{array}{r}Y_{2} \\
0.03\end{array}$} & \multirow{2}{*}{$\begin{array}{l}\left.P X=\phi V_{1}\right) \\
0.93\end{array}$} & \multirow{2}{*}{$\begin{array}{l}\left.P X=Q V_{2}\right) \\
0.97\end{array}$} & & & & \\
\hline 0,50 & & & & & 0,465 & 0,485 & 0,518 & 0,504 \\
\hline 0,30 & 0,11 & 0,04 & 0,89 & 0,96 & 0,267 & 0,288 & 0,297 & 0,299 \\
\hline 0,20 & 0,17 & 0,05 & 0,83 & 0,95 & 0,166 & 0,190 & 0,185 & 0,197 \\
\hline & & & & & $\sum$ & & 1,000 & \\
\hline
\end{tabular}

*nastavak prethodne tabele

\begin{tabular}{|r|r|r|r|}
\hline \multicolumn{2}{|c|}{ Plaćanja $(€)$} & \multicolumn{2}{|c|}{ Žaljenje $(€)$} \\
\hline$a_{l}$ & \multicolumn{1}{|c|}{$\mathrm{a}_{2}$} & $a_{l}$ & $\mathrm{a}_{2}$ \\
\hline 231 & 882 & 120 & 444 \\
\hline 363 & 1.176 & 109 & 352 \\
\hline 561 & 1.470 & 104 & 290 \\
\hline
\end{tabular}




\section{PRILOG 4}

Tabela odlučivanja za $X=1$

\begin{tabular}{|c|c|c|c|c|c|c|c|c|}
\hline \multirow{3}{*}{$\begin{array}{l}\text { Apr. } \\
\text { ver. }\end{array}$} & \multicolumn{2}{|c|}{ Kriterijum } & \multicolumn{2}{|c|}{ Uslovna } & \multirow{2}{*}{\multicolumn{2}{|c|}{$\begin{array}{l}\text { Složena } \\
\text { verovatnoća }\end{array}$}} & \multirow{2}{*}{\multicolumn{2}{|c|}{$\begin{array}{l}\text { Aposteriorna } \\
\text { verovatnoća }\end{array}$}} \\
\hline & \multirow[b]{2}{*}{$Y_{1}$} & \multirow[b]{2}{*}{$Y_{2}$} & \multirow[b]{2}{*}{$P\left(X=\| y_{1}\right)$} & \multirow[b]{2}{*}{$P\left(X=\| y_{2}\right.$} & & & & \\
\hline & & & & & \multicolumn{2}{|c|}{$P\left(Y_{2}\right) \cdot P\left(X_{i} \mid Y_{2}\right)$} & \multicolumn{2}{|c|}{$P\left(Y_{2}\right)$} \\
\hline 0,50 & 0,07 & 0,03 & 0,07 & 0,03 & 0,035 & 0,015 & 0,343 & 0,343 \\
\hline 0,30 & 0,11 & 0,04 & 0,11 & 0,04 & 0,033 & 0,012 & 0,323 & 0,323 \\
\hline 0,20 & 0,17 & 0,05 & 0,17 & 0,05 & 0,034 & 0,010 & 0,334 & 0,334 \\
\hline & & & & & & 1,000 & 1,000 \\
\hline
\end{tabular}

*nastavak prethodne tabele

\begin{tabular}{|c|r|r|c|}
\hline \multicolumn{2}{|c|}{ Plaćanja } & \multicolumn{2}{c|}{ Žaljenje } \\
\hline$a_{\nearrow}$ & $\mathrm{a}_{2}$ & $a_{\nearrow}$ & \multicolumn{1}{c|}{$\mathrm{a}_{2}$} \\
\hline 231 & 882 & 79 & 302 \\
\hline 363 & 1.176 & 117 & 380 \\
\hline 561 & 1.470 & 187 & 491 \\
\hline
\end{tabular}

\section{PRILOG 5}

\section{Proracun Bajesovom metodom}

Isporučilac1 : Livnica "Kikinda', , Srbija

Isporučilac2 : Livnica "Maćkatica", , Srbjja

Isporučila03 : Żèezara "Lijaš",, BiH

\begin{tabular}{|c|c|c|c|c|c|c|c|c|c|c|c|c|c|c|c|}
\hline \multicolumn{4}{|c|}{ OWZIIFOACI } & \multicolumn{4}{|c|}{ Ualone verovitude } & \multicolumn{4}{|c|}{ sulene verowatide } & \multicolumn{4}{|c|}{ 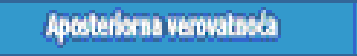 } \\
\hline \multirow[b]{2}{*}{ Iopenălos } & \multirow{2}{*}{ 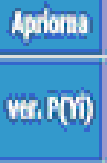 } & \multicolumn{2}{|c|}{ Kiteiflum } & \multicolumn{2}{|c|}{$\eta=0$} & \multicolumn{2}{|c|}{$x=1$} & \multicolumn{2}{|c|}{$x=0$} & \multicolumn{2}{|c|}{$x=1$} & & & & \\
\hline & & $\mathrm{u}$ & $Y 2$ & (Pii) & $P(2)$ & P(ii) & $P(2)$ & $\begin{array}{l}P(1) \times p \\
\text { (vi) }\end{array}$ & $\begin{array}{l}(10) 0 \mathrm{p} \\
(\mathrm{p})\end{array}$ & $\begin{array}{l}\text { (1) } \\
\text { (ii) }\end{array}$ & $\begin{array}{c}\mathrm{F}(\mathrm{N}) \mathrm{CP} \\
(\mathrm{C})\end{array}$ & \multicolumn{2}{|c|}{$\mathrm{F}(\mathrm{Vi})$} & \multicolumn{2}{|c|}{$P(2)$} \\
\hline : & 0.5 & 0.07 & 0.03 & 0.93 & 0.97 & 0.07 & 0.03 & 0.455 & 0.465 & 0.05 & 0.015 & 0.518 & 0.504 & 0.943 & 0.465 \\
\hline 2 & 0.3 & 0.11 & 0.04 & 0.99 & 0.96 & 0.11 & 0.04 & 0.267 & 0.260 & 0.038 & 0.012 & 0.297 & 0.29 & 0.34 & 0.284 \\
\hline 3 & 0.2 & 0.17 & 0.05 & 0.83 & 0.58 & 0.17 & 0.05 & 0.168 & 0.19 & 0.044 & $0.0:$ & 0.125 & 0.197 & 0.203 & 0.27 \\
\hline
\end{tabular}

Softversko rešenje proračuna Bajesovom metodom 